\title{
The influence of Blended Learning to improve students' confidence in speaking achievement
}

\author{
Ajeng Putri Widiarti' ${ }^{1}$, Hery Yufrizal ${ }^{2}$, Sudirman ${ }^{3}$ \\ FKIP Universitas Lampung, Jl. Prof. Dr. Sumantri Bojonegoro, Rajabasa, Bandar Lampung ${ }^{1,2,3}$ \\ ${ }^{1}$ Correspondence: ajengpwidiarti@gmail.com
}

Abstract: The aims of this research were to find out whether there was a significant difference on students' speaking achievement and students' confidence after the implementation of Blended Learning. This research was a quantitative with one group pre-test and post-test design. Speaking test and questionnaire of students' confidence were used to collect the data. The subjects were 32 students of class XI Science 4 of SMAN 2 Bandar Lampung. The data of speaking test were analyzed by using Paired Samples T-test. The questionnaire was in form of scores and analyzed by using Cronbach's Alpha. The results show that there was a significant difference on students' speaking achievement and improvement of students' confidence. This suggests that Blended Learning can influence the students to improve their confidence in speaking achievement.

Keywords: Blended learning, confidence, speaking achievement.

\section{INTRODUCTION}

English is an international language and many students use English for their communication to each other. And it is a requirement in globalization era at this moment. In Indonesia, there are not many of the citizen using English as a means of communication. English is used just for formal occasion not in informal occasion that cause only a few Indonesian can speak English. The importance of English as the key to the international communication and commerce makes it a compulsory subject for Senior High School. According to the current curriculum, English Curriculum 2013 in Senior High School' aims are to set the students to get ready for communication in spoken and written English and to make the students achieve informational level of communication. It means that the students have to master English, in order that they are easier to go to the higher level. Talking about English means talking about four language skills, they are, listening, speaking, reading and writing.

Speaking is a language skill of oral communication to express human idea, feeling, option, and thought or information which helps people to communicate one other (Chaney and Burke, 1998). This means people can express their felling and understand what the other say. Learning language does not mean just learning about structure and vocabulary but the important thing is learning how to use language for communication to others, how we speak and make the others understand what we talk.

A lot of students feel that speak in a new language is harder than reading, writing, or listening for two reasons (Nunan, 2003). It also happened to the students in senior high school. Jisda (2014) states that the students sometime faced many problems in learning English especially in 
speaking for example some students were difficult to produce some words in English, they were afraid of being criticized, they also did not get opportunities to train their speaking skill in class.

On the other hand, Ghassanie (2015) who involved SMAN 1 Palembang showed that second grade students found it hard to speak. For example, they were not confident enough in speaking in class and confused how to express their ideas.

Usually, the students do not feel comfortable to speak in the class because they have not a good confidence. They always think about what will the others say when they speaking. A good selfconfidence not only concerned in how excellent their grammar, but speaker has to communicate with the listener and make the listener understand about the information being delivered by the speaker. There are many instruments to improve the students' confidence. One of them is using blended learning as a supporting tool.

Learning English involves students' confidence, motivation, sociocultural perspective. Confidence will take core part in communicating with others as Doqaruni (2013) states that the students who are active in class seems to have higher confidence than those who are passive in class.

Previous researcher has been doing a research of the correlation of confidence and speaking and how to build it. Doqaruni (2013) had done a research on demonstrating confidence in English class. The participants were 16 Iranian university students in private English language institute. He found that the students, at first time, seemed passive during learning process in the class happened. He used to add extra speaking activities, story telling, and presentation activities. The result showed that an instructional methodology stressing on peer collaboration as a tool for increasing students' speaking achievement is likely to result in confidence (Doqaruni, 2013).

From the researcher's experiences, however, some students' keep silent all the time in English class. They do not want to speak even they know the answer or correct one. They hesitate to speak out due to several reasons, like they are shy, they are nervous, and they are afraid of losing face (e.g being laughed at), previous negative experience in English class. Regardless of the problem occured in the teaching learning activity, most of teaching learning activity in senior high school focused only on reading-listening-writing which those skills are examined in final examination. On the ordinary, they are weak in speaking achievement. It is caused by their levels of practicing is low.

Problem stated the lack of confidence happen to the students is because the lack of speaking practices during the teaching learning activity. Based on the problem, the teaching learning activity seems necessary to be changed into an activity which motivates students' to speak and build their confidence. Blended learning is a technique to help the students to build their confidence in speaking English.

According to Albrecht (2006), this is kind of model which combines both face-to-face classroom activity and online class learning is called blended learning. In fact, there are some previous researches with respect to this kind of teaching and learning style. They prove that blended learning is effective to improve English vocabulary level (Djiwandono, 2013), and it is 
also suitable to improve listening skill (Sofiana, 2015). That is why this research is conducted to find out whether blended learning is also suitable to build students' confidence in speaking achievement.

Furthermore, we need to decide an application that might be appropriate for the online class used by the students. We have to choose the simplest application to use. One of the best familiar applications that used by everyone nowadays is WhatsApp. WhatsApp can be suitable to be applied as the media to help the students to acquire English and build their confidence. It is a free and simple accessible chatting aplication of which feature allows the users to share and receive picture, audio, and video. So, it has complete feature that can be utilized in the process of acquiring English.

The motive of finding this also came from the author's experience. She has been learning English at Pare, Kediri in 2018. She had lack of confidence while learning in speaking class. At the moment, her teacher asked the students in the class to use voice note in WhatsApp to collect an assignment and also to use a song to accompany her during speaking. Thus, her teacher was inspired her to study more about this technique.

In short, students' confidence in speaking achievement hopefully can be improved by applying this kind of blended learning. By following blended class, the second grade of senior high school students will enjoy and be comfortable to speak up.

\section{METHODS}

\section{Participants}

This research was conducted in the second grade students of SMAN 2 Bandar Lampung. The subject of the research was class XI Science 4 consisting of 32 students. The research was conducted three offline meetings and three online meetings.

\section{Instruments}

There are two instruments of this research: the speaking test and the questionnaire of selfconfidence.

\section{Data Analysis}

The researcher analyzed the result and calculated the scores for speaking tests by using Paired Sample T-test. To see students' confidence, the researcher shared an close-ended questionnaire. The questionnaire was analyzed by using Cronbach's Alpha of Statistical Package for Social Science (SPSS) version 20. Meanwhile, to analyze normality of the data, the researcher used Shapiro-Wilk row in SPSS.

\section{RESULTS AND DISCUSSIONS}

\section{Results}

In classifying the students' confidence toward the technique to the questionnaire, the researcher used low, medium and high categorizes. There are 4 students $(12.5 \%)$ of XI IPA 4 
in low categorize, 16 students $(50.0 \%)$ in medium categorize and 12 students $(37.5 \%)$ in high categorize out of 32 students. A number of students who in medium and high categorize are more than low categorize. The data were analyzed by using SPSS.

In the pre-test, the students had not good scores; moreover, their scores increased in the post-test. Surprisingly, in the post-test all of them increased significant enough, although some students had just a bit increase. Even there were five of them whose scores were very good. Furthermore, to prove this result paired samples t-test was used. The mean score of pre-test is 63,06. According to the categorization, it is categorized as enough. In the post-test, students' speaking achievement is improved to 81,19 . It is categorized as good.

Normality of the data that are using paired sample t-test must have a normal distribution. The researcher used the level of significance 0.05 in which the hypothesis was proved if $\operatorname{sign}<\mathrm{p}$. It means that the probability of error in the hypothesis was only $5 \%$. The significant values used in this test are from the Shapiro-Wilk row because the elements were only thirty two. According to the table above, it can be seen that the significant level of each test was higher than $0.05 \quad(0.529>0.05 ; 0.186>0.05)$. Thus, it means that the data have normal distribution.

Paired Samples Test

\begin{tabular}{|c|c|c|c|c|c|c|c|c|c|}
\hline & & \multicolumn{5}{|c|}{ Paired Differences } & \multirow[t]{3}{*}{$\mathrm{t}$} & \multirow[t]{3}{*}{$\mathrm{df}$} & \multirow{3}{*}{$\begin{array}{l}\text { Sig. (2- } \\
\text { tailed) }\end{array}$} \\
\hline & & \multirow[t]{2}{*}{ Mean } & \multirow[t]{2}{*}{$\begin{array}{c}\text { Std. } \\
\text { Deviation }\end{array}$} & \multirow[t]{2}{*}{$\begin{array}{l}\text { Std. } \\
\text { Error } \\
\text { Mean }\end{array}$} & \multicolumn{2}{|c|}{$\begin{array}{c}95 \% \text { Confidence } \\
\text { Interval of the } \\
\text { Difference }\end{array}$} & & & \\
\hline & & & & & Lower & Upper & & & \\
\hline $\begin{array}{l}\text { Pair } \\
1\end{array}$ & $\begin{array}{l}\text { Pretest - } \\
\text { Posttest }\end{array}$ & $\begin{array}{r}- \\
18,125\end{array}$ & 3,170 &, 560 & $-19,268$ & $-16,982$ & $\begin{array}{r}- \\
32,345\end{array}$ & 31 &, 000 \\
\hline
\end{tabular}

The results show that there was a significant difference on students' speaking achievement and improvement of the students' confidence. This suggests that Blended Learning can influence the students to improve their confidence in speaking achievement.

\section{Discussion}

\section{Discussion of the Significant Difference and the Improvement of Students' Speaking Achievement through Blended Learning Technique}

This research showed that the implementation of blended learning technique can improve students' speaking achievement. There was a significant difference of students' speaking achievement after the implementation of blended learning. It is done through testing the $\mathrm{p}$ value. The result of difference of students' pre-test and post--test shows that $p$ value is 0.000 , which means it is $<0.05$. The students' achievement is improved. The data also show that the mean difference of students score is 18,12 . 
The improvement of the students' speaking achievement could be seen from their score in pretest and posttest. After the researcher implemented the technique in the class, it is known that there is an increase of the students' speaking achievement. The improvement's result shows that is the pre-test 63,06 and post-test 81,19 , also the mean score 18,12 . It indicates that blended learning technique made students improve their speaking achievement.

After the blended learning technique applied, the researcher found that the process of teaching using blended learning makes students more confident, a lot of new vocabularies, fluent and effective in doing conversation in learning process. According to Albrecht (2006), this is kind of model which combines both face-to-face classroom activity and online class learning is called blended learning. In its application, blended learning uses group discussion as the method. Lightbown and Spada (1993) stated that group discussion is an activity that can be applied in a language classroom that can lead to increase fluency and the ability to manage conversations more effectively in a second language, the students are encouraged to talk and share their idea not only through offline group but also online group which is considered as blended learning. Thus, the technique is useful for the second grade of SHS to improve their fluency, because as we know, sometimes they have a lot of ideas and thoughts but lack of confidence to express it.

Previous researcher has been doing a research of the correlation of confidence in speaking and blended learning. Djiwandono (2013) proved that blended learning is effective to improve English vocabulary level and it also suitable to improve listening skill (Sofiana, 2015).

According to the findings of the previous researches and in this research, the students' gained significant improvement after the implementation of blended learning for their confidence. Doqaruni (2013) implemented story telling activities and presentation in promoting students self-confidence. He found the students' self-confidence and speaking ability increased after the implementation of the incorporated activities. Also, Agung Putra (2017) has proved that the students' confidence can be improved by doing group discussion technique in speaking class. The improvement of students not only in confidence, but also in aspects of speaking which are vocabulary, comprehension and fluency on the top of rank.

There is statistically significant improvement from the students in all aspects of speaking including pronunciation, grammar, vocabulary, fluency, and comprehension. The result shows that there are three aspects improved the most, vocabulary, comprehension, and fluency. First, Wilkins (1983) states that vocabulary is important in speaking, without words we cannot speak. In the beginning, most of the students are usually hesitate to express their ideas in oral. During the implementation of blended learning, they are forced to much listening, practicing, and drilling in English. The result also shows that the gain of vocabulary is 0.59883 with level of significance $0.000<0.05$. It is in the first rank of speaking aspects which improved significantly. This aspect is the most influence the students' speaking achievement. Second, comprehension is the ability to understand the speaker intention in communication. In implementing blended learning, the students are requisited to respond what the others said. So, it implies that if someone can respond well it means he comprehends well. The result shows that the gain of comprehension is 0.52121 with level of significance $0.000<0.05$. Comprehension is in the second rank of speaking aspects which had statistically significant improvement that is influenced the students' speaking achievement. Third, Harris (1987) says that fluency is the 
speed of the flow of speech, the ability to speak communicatively and fluently. This aspect improved the most because of the students practice on and on during the learning process. The result shows that the gain of fluency is 0.45111 with level of significance $0.000<0.05$. Thus, their fluency improved after the implementation of the technique. In the fourth and last are pronunciation and grammar which is improved. It can be concluded that in the result, the aspests with highest increase is vocabulary, comprehension, and fluency. These aspects can make the students be more confidence by drilling in offline and online class.

Related to the response and learning process of the students, it showed that blended learning gave some positive effects for the students. This proved by the good response and answer from the students about the blended learning technique. Firstly, blended learning technique influenced the students to improve their confidence. Secondly, they are more practicing and drilling in speaking English. Thirdly, it facilitated the students to develop their vocabularies and comprehension. Fourthly, the students are being more fluent than before. Last, they are brave to speak up in the class.

Having considered the explanation above, we can conclude that the blended learning technique is suitable to improve students' speaking skill. Therefore, blended learning technique gave positive impacts of the students' confidence and their speaking achievement.

\section{Discussion of the Influence between Students' Improvement on Speaking Achievement and Confidence through Blended Learning Technique}

The researcher found that blended learning technique influenced their improvement of confidence on speaking achievement rather than traditional technique. This technique leads the students more practicing and drilling in speaking whether in online and offline class. Moreover, the students are more brave and master in some aspects of speaking.

Blanded learning technique give positive impacts to the students in their learning process by analyzing the students' questionnaire. They are being more brave and fluent in English because of drilling many times. There are three aspects of speaking that improve the most like vocabulary, comprehension and fluency.

Confidence will take core part in communicating with others as Doqaruni (2013) states that the students who are active in class seems to have higher confidence than those who are passive in class. Consequently, the more confident the students, the greater communicative competence they achieve and the better psychological adjustment and cross-cultural adaption their experience.

Thus, it can be justified that there is influences between students' improvement on speaking achievement and their confidence toward the blended learning technique. As Doqaruni (2013) proved that the students with high self-confidence will involve actively during the learning activity rather than those with low self-confidence. The researcher found that actually the students have a lot of ideas and thoughts to response what the others said, but they are usually lack of confidence, hesitate and afraid of being wrong. So, it can influence their speaking in English. Moreover, it can be concluded that the more students have high confidence the more 
their speaking achievement improved. The researcher proved that blended learning can influence the students to reach more confidence by practicing and drilling many times in online and offline class. The students who are in the beginning have lack of confidence, after the implementation of blended learning being more fluent and confident when speaking English.

\section{CONCLUSIONS AND SUGGESTIONS}

\section{Conclusions}

After conducting this research in class XI Science 4 and analyzing the data, it can be concluded that students speaking achievement improved significantly after being taught by blended learning. moreover, blended learning provides an activity which enhances the students to speak up, and have an active learning process, group discussion collaboration. The students will have more speaking improvement since blended learning provides a debating environment where they will express their opinions. Surprisingly, vocabulary which is one of speaking aspects had the most improvement from those five aspects of speaking. Although majority of the students improved significantly in their speaking achievements, few of them have just little improvement. Furthermore, the students who have little improvement in posttest, it seems they were not confident enough with the topics in learning process. However, majority of the students have significant improvement in speaking achievement and also influence their confidence.

\section{Suggestions}

Relating to the conclusion, the researcher would like to give some suggestions. Suggestion for teachers, the communicative environment in blended learning is needed to build students' confidence, media like video and short clip should be featured when doing online class to trigger the students to join and suitable materials is needed to prepare the learning process occur in good ways. The materials should be taken from syllabus and curriculum for the appropriate semester and class. There are some suggestions for further researchers, this research aims were to improve both of the students' confidence and speaking achievement through blended learning, thus the researcher suggests to the next researcher to analyze the students' confidence and the correlation to their personality in learning English and the treatments should be applied more than just 3 meetings to get more accurate result of the data. The more time you do the treatments, the more you get the best result.

\section{REFERENCES}

Arikunto, S. 2006. Prosedur penelitian: suatu pendekatan praktik. Jakarta: Rineka Cipta. Brown, G., and Yule, G. 1983. Teaching the spoken language. United Kingdom: Cambridge University Press.

Brown, G., and Yule, G. 1983. Discourse analysis. Cambridge: Cambridge University Press.

Brown, H. D. 2001. Principles of language learning and teaching, $4^{\text {th }}$ edition. Cambridge: Pearson Longman Press. 
Bryne, D. 1986. Teaching oral English: Longman handbooks for English teacher.

Burns, A., \& Joyce, H. 1997. Focus on speaking. Sydney: National Center for English Language Teaching and Research. Singapore: Longman Group

Djiwandono, P. I. 2013. A blended learning approach to enhance college students' vocabulary learning. Electronic journal of foreign language teaching,10(2). 210-220. Singapore: Center for Language Studies National University of Singapore.

Doqaruni, R.V. 2013. A quantitative action research on promoting confidence in a foreign language classroom: implications for second language teachers. Inquiry in Education, $5(3), 1-20$.

Ghassanie, S. F. 2015. The effectiveness of using galery Work Strategy in Improving Students' Speaking Achievement of the tenth grade Students of SMK Negeri 2 Palembang. Indralaya: Sriwijaya University. (Unpublished thesis)

Griffee, D. T. 1996. Validation and classroom research instrument and product. The Journal of Seigakuin University, 9(1), 53-70.

Harmer, J. How to teach english new edition. England: Longman

Harris, D. 1974. Testing english as a second language. New York: McGraw Hill Book Company.

Hatch, E., \& Farhady, H. 1982. Research design and statistic for applied linguistics. Rowley: Newburry House Publisher. Inc.

Heaton, J. B. 1991. Writing English language testing. New York: Longman. Inc

Ivone, F. 2005. Teaching English as a foreign language in Indonesia: the urge to improve classroom vocabulary instruction. TEFLIN Journal, 16(2), 195-208.

Jisda, A. W. 2014. Public Knowledge Project: Teaching Speaking by Combining Talking Chip and Numbered Heads Strategies for Senior High School. Retrieve December $4^{\text {th }}$, 2018.

Kayi, H. 2006. Teaching speaking: activities to promote speaking in a second language. The internet of TESL journal, 12(11) Nevada: University of Nevada.

Nunan, D. 1991. Language teaching methodology: A textbook for teachers. New York: Prentice Hall International, Ltd.

Nunan, D. 2003. The impact of English as a global language on educational policies and practices in the Asia-Pacific Region. TESOL Quarterly. Vol. 37, No. 4: pp. 589-613.

Richards, J. 2016. Teaching listening and speaking - from theory to practice: an introduction. Cambridge: Cambridge University Press.

Setiyadi, Ag. B. 2006. Teaching English as a foreign language Yogyakarta: Graha Ilmu.

Setiyadi, Ag. B. 2006. Metode penelitian untuk pengajaran bahasa asing pendekatan kuantitatif dan kualitatif.. Yogyakarta: Graha Ilmu.

Shohamy. 1985. A practical Handbook in language testing for the second language teacher. Tel Aviv: Tel Aviv University.

Sofiana, N. 2015. Implementation of blended learning in an extensive listening class. Jurnal Tarbawi, 12(1), 59-70.

Susanti, E. 2017. Boosting-Students'-Motivation-in-Speaking-through-Blended- Learning-1. UHAMKA International Conference on ELT and CALL (UICELL) Jakarta, 1-8.

Weltys, D. 1976. The teacher aids in the Instruction Team. New York: Mc. Graw Hill. 